\title{
MANFAAT PEMBELAJARAN SEJARAH MENGGUNAKAN GOOGLE CLASSROOM PADA MASA PANDEMI COVID-19
}

\author{
Marharjono \\ SMA Negeri 1 Sewon \\ marhar.jono15@gmail.com
}

\begin{abstract}
Abstrak: Tujuan penulisan artikel ini untuk mengetahui pelaksanaan dan nilai nilai pembelajaran sejarah menggunakan Google Classroom masa pandemic covid-19 pada kelas XI MIPA 2 di SMA Negeri 1 Sewon. Pelaksanaan pembelajaran berlangsung delapan kali pertemuan. Manfaat pembelajaran daring menggunakan Google Classroom peserta didik dapat mengatahui sejarah peristiwa sekitar proklamasi, pembentukan pemerintahan Republik Indonesia, perjuangan menghadapi kekuasaan Jepang, perjuangan menghadapi kedatangan Sekutu dan Belanda, serta perjuangan meghadapi aancaman Belanda melalui konfontasi militer dan deplomasi. Kelebihan penggunaan Google Classroom, guru dan peserta didik menjadi terbiasa menggunakan pembelajaran daring. Hambatan penggunaan Google Classroom, guru dan peserta didik tidak dapat bertatap muka langsung dalam pembelajaran. Apabila sarana kurang memadai dapat menghambat pembelajaran daring. Nilai-nilai mempelajari materi sejarah revolusi kemerdekaan Indonesia antara lain: 1) sabar dan bijaksana; 2) kerja keras; 3) rela berkorban tanpa pamrih; 4) pantang menyerah; 5) nasionalisme; 6) cinta tanah air; 7) saling menghargai.
\end{abstract}

Kata kunci: belajar, Google Classroom, Covid-19

\section{BENEFITS OF LEARNING HISTORY USING GOOGLE CLASSROOM AT THE COVID-19 PANDEMIC PERIOD}

\begin{abstract}
The purpose of this study is to determine the implementation and historical learning values using google classroom during covid-19 pandemic at class XI MIPA 2 in SMA Negeri 1 Sewon. The learning process took place eight times. The benefits of using google classroom for online history learning were student able to know the history of events around the proclamation, the formation of the government of the Republic of Indonesia, the struggle against Japanese rule, the struggle against the arrival of the Allies and the Netherlands, as well as the struggle against the threat of the Netherlands through military confrontation and deplomation. By using google classroom, teachers and students become accustomed with online learning. However, the utilization of google classroom can not enable synchronous learning between teachers and students. Inadequate facilities may obstruct this online learning method. The values of studying history of the Indonesian independence revolution include : 1) patient and wise; 2) hard work; 3) willing to sacrifice selflessly; 4) never give up; 5) nationalism; 6) patriotism; 7) mutual respect.
\end{abstract}

Keywords: learning, Google Classroom, Covid-19

\section{PENDAHULUAN}

Undang-Undang Nomor 20 Tahun 2003 tentang Sistem Pendidikan Nasional pada pasal 1 (2003 : 6) dijelaskan bahwa pendidikan adalah usaha sadar terencana untuk mewujudkan suasana belajar dan proses pembelajaran agar siswa secara aktif dapat mengembangkan potensi dirinya untuk memiliki kekuatan spiritual keagamaan, pengendalian diri, kepribadian, kecerdasan, aklak mulia, serta ketrampilan yang diperlukan dirinya, masyarakat, bangsa dan negaranya. serta dalam pembentukan manusia Indonesia yang memiliki rasa kebangsaan dan cinta tanah air.

Menghadapi era revolusi Industri abad 4.0 yang juga berlaku di Indonesia dengan tingkat persaingan yang semakin ketat. Dari sejumlah perubahan yang harus dilakukan, perbaikan sumber daya manuasia adalah salah satu hal yang harus sangat diperhatikan. Perbaikan tersebut dapat terlaksana salah satunya dengan cara mengubah metode pembelajaran dalam dunia pendidikan yang ada. Setidaknya ada tiga hal yang perlu diubah dari sisi edukasi. Pertama dan yang paling fundamental adalah mengubah sifat dan pola pikir anak-anak muda Indonesia saat ini. Kedua, pentingnya peran sekolah dalam mengasah dan mengembangkan bakat generasi penerus bangsa. Ketiga dan yang terakhir adalah pengembangan kemampuan institusi pendidikan tinggi untuk mengubah model pembelajaran yang sesuai dengan 
kebutuhan zaman saat ini. (Prasetiya Mulya, $2018: 1)$

Dewasa ini berbagai negara di dunia, tengah dikejutkan dengan wabah suatu penyakit yang disebabkan oleh virus bernama corona atau lebih dikenal dengan istilah covid19 (Corona Virus Diseases-19). Penyebaran virus covid-19 menjadi penyebab angka kematian yang paling tinggi di berbagai negara dunia saat ini. Sudah banyak korban yang meninggal dunia. Bahkan banyak juga tenaga medis yang menjadi korban lalu meninggal. Hal ini menjadi permasalahan yang harus dihadapi oleh dunia saat ini, untuk melakukan berbagai kebijakan termasuk di negara Indonesia. Negara Indonesia juga merasakan akan dampak penyebaran virus ini. Semakin hari semakin cepat menyebar ke sejumlah wilayah di Indonesia.

Pemerintah menerapkan kebijakan yaitu Work From Home (WFH). Kebijakan ini merupakan upaya yang diterapkan kepada masyarakat agar dapat menyelesaikan segala pekerjaan di rumah. Pendidikan di Indonesia pun menjadi salah satu bidang yang terdampak akibat adanya pandemi covid-19 tersebut. Dengan adanya pembatasan interaksi, Kementerian Pendidikan di Indonesia juga mengeluarkan kebijakan yaitu dengan meliburkan sekolah dan mengganti proses Kegiatan Belajar Mengajar (KBM) dengan menggunakan sistem dalam jaringan (daring). Dengan menggunakan sistem pembelajaran secara daring ini, kadang-kadang muncul berbagai masalah yang dihadapi oleh siswa dan guru, seperti materi pelajaran yang belum selesai disampaikan oleh guru kemudian guru mengganti dengan tugas lainnya. Hal tersebut menjadi keluhan bagi siswa karena tugas yang diberikan oleh guru lebih banyak (Rani Puspitasari, $2020: 1$ ).

Surat Edaran Nomor 4 Tahun 2020 Kementerian Pendidikan dan Kebudayaan Republik Indonesia tentang Pelaksanaan Kebijakan Pendidikan Masa Darurat Covid-19, dijelaskan 1) Belajar dari rumah melalui pembelajaran daring/jarak jauh dilaksanakan untuk memberikan pengalaman belajar yang bermakna bagi peserta didik tanpa terbebani tuntutan menuntaskan seluruh capaian kurikulum untuk kenaikan kelas maupun kelulusan. 2) Belajar dari rumah dapat difokuskan pada pendidikan kecakapan hidup antara lain mengenai pandemi Covid-19. 3) Aktivitas dan tugas pembelajaran dari rumah dapat bervareasi antarpeserta didik, sesuai dengan minat dan kondisi masing-masing termasuk mempertimbangkan akses/fasilitas belajar di rumah. 4) Bukti atau aktifitas belajar dari rumah diberi umpan balik yang bersifat kualitatif dan berguna dari guru tanpa diharuskan memberi skor / nilai kuantitatif.

Sebelum adanya pandemi covid-19 pembelajaran di SMA Negeri 1 Sewon dilaksanakan dengan tatap muka pembelanjaran langsung di kelas, hanya sebagian saja guru yang menggunakan pembelajaran online di kelas. Dengan diberlakukannya masa tanggap darurat pandemi covid-19 SMA Negeri 1 Sewon juga melaksanakan pembelajaran daring/jarak. Persiapan dilaksanakan oleh sekolah dengan mengadakan Workshop pembelajaran daring atau pembelajaran jarak jauh bagi semua guru SMA Negeri 1 Sewon pada hari Rabu, tanggal 18 Maret 2020 pukul 13.00 - 15.30 WIB. dengan materi penggunaan Geoogle Classroom.

Penulis sebagai guru yang mengampu mata pelajaran Sejarah di SMA Negeri 1 Sewon pada tulisan ini akan memaparkan pengalaman mengajar dengan menggunakan Google Classroom pada Kelas XI MIPA 2. Google Classroom dipilih dan digunakan dalam pembelajaran karena guru pernah mengikuti workshop penggunaan media Google Classroom. Penggunaan media tersebut juga lebih familier dibandingkan aplkasi yang lainnya dan jika ada kendala tehnis penggunaan bisa bertanya pada guru yang lain yang lebih menguasai penggunaan media Google Classroom.

Rumusan masalah dalam penelitian ini adalah: Bagaimana pelaksanaan dan nilai nilai pembelajaran sejarah menggunakan Google Classroom di SMA Negeri 1 Sewon. Tujuan penulisan artikel ini adalah untuk mengetahui pelaksanaan dan nilai nilai pembelajaran sejarah menggunakan Google Classroom di SMA Negeri 1 Sewon.

\section{KAJIAN PUSTAKA Belajar}

Belajar pada dasarnya merupakan aktivitas manusia yang dilakukan sepanjang hayatnya, dalam arti luas belajar adalah kegiatan psiko-fisik menuju ke perkembangan pribadi seutuhnya, sedangkan dalam arti sempit belajar merupakan usaha penguasaan materi ilmu pengetahuan yang merupakan sebagian kegiatan menuju terbentuknya kepribadian seutuhnya (Sardiman, 2009:20-21). 
Belajar dapat diartikan suatu proses usaha yang dilakukan seseorang untuk memperoleh suatu perubahan yang baru, sebagai hasil pengetahuan sendiri dalam interaksi dengan lingkungannya (Sutikno, 2013:2). Belajar diartikan pula sebagai suatu proses perubahan tingkah laku individu melalui interaksi dengan lingkungan (Hamalik, 2003:28).

\section{Pembelajaran Jarak Jauh / daring}

Pembelajaran jarak jauh adalah ketika proses pembelajaran tidak terjadi kontak dalam bentuk tatap muka langsung antara pengajar dan pembelajar. Komunikasi berlangsung dua arah yang dijembatani dengan media seperti computer, telivisi, radio, telepon, internet, vedio dan sebagainya. (Munir, 2012:16).

Holmeberg (dalam Munir, 2012:19) menyatakan bahwa dalam pembelajaran jarak jauh pembelajar belajar tanpa mendapatkan pengawasan langsung secara terus dari pengajar atau tutor yang hadir di ruang belajar atau di lingkungan tempat belajarnya. Namun pembelajar mendapatkan perencanaan, bimbingan, dan pembelajaran dari lembaga yang mengelola pendidikan jarak jauh itu. Fokus dari batasan Holmberg adalah bahwa pembelajat dan pengajar berkerja secara terpisah, dan adanya perencanaan pembelajaran yang dilakukan oleh suatu lembaga pendidikan yang mengatur pendidikan jarak jauh.

\section{Mata Pelajaran Sejarah}

Sejarah adalah semua yang kita ketahui mengenai segala sesuatu yang telah dilakukan atau dipikirkan atau diharap atau dirahasiakan oleh manusia (Suhardi Marli, 2011:2). Menurut BNSP sejarah adalah cabang ilmu pengetahuan yang menelaah tentang asal-usul dan perkembangan serta peranan masyarakat di masa lampau berdasarkan metode dan metodologi tertentu. Terkait dengan pendidikan di sekolah dasar hingga sekolah menengah, pengetahuan masa lampau tersebut mengandung nilai-nilai kearifan yang dapat digunakan untuk melatih kecerdasan, membentuk sikap, watak dan kepribadian peserta didik (BSNP, 2006:187).

Tujuan Mata Pelajaran Sejarah, BSNP (2006:188) menyatakan bahwa mata pelajaran Sejarah bertujuan agar peserta didik memiliki kemampuan sebagai berikut:

a. Membangun kesadaran peserta didik tentang pentingnya waktu dan tempat yang merupakan sebuah proses dari masa lampau, masa kini, dan masa depan. b. Melatih daya kritis peserta didik untuk memahami fakta sejarah secara benar dengan didasarkan pada pendekatan ilmiah dan metodologi keilmuan.

c. Menumbuhkan apresiasi dan penghargaan peserta didik terhadap peninggalan sejarah sebagai bukti peradaban bangsa Indonesia di masa lampau.

d. Menumbuhkan pemahaman peserta didik terhadap proses terbentuknya bangsa Indonesia melalui sejarah yang panjang dan masih berproses hingga masa kini dan masa yang akan datang.

e. Menumbuhkan kesadaran dalam diri peserta didik sebagai bagian dari bangsa Indonesia yang memiliki rasa bangga dan cinta tanah air yang dapat diimplementasikan dalam berbagai bidang kehidupan baik nasional maupun internasional.

\section{Google Classroom}

Google Classroom atau ruang kelas Google merupakan suatu serambi pembelajaran campuran untuk ruang lingkup pendidikan yang dapat memudahkan pengajar dalam membuat, membagi dan menggolongkan setiap penugasan tanpa kertas (paperless) software tersebut telah diperkenankan sebagai keistimewaan dari Google Apps for Educattion rilis pada tanggal 12 Agustus 2014.

Menurut website resmi dari Google media Google Classroom merupakan alat produktivitas gratis meliputi email, dokumen dan penyimpanan Classroom didesain untuk memudahkan guru (pengajar) dalam menghemat waktu, mengelola kelas dan meningkatkan komunikasi dengan peserta didikpeserta didiknya. Dengan Google Classroom ini dapat memudahkan peserta didik dan pengajar untuk saling terhubung di dalam dan di luar sekolah. Rosemarie DeLoror seorang guru asal New York, menyatakan selama 60 tahun Ia mengajar tidak pernah sekalipun menggunakan computer. Namun sejak memiliki Chromebook dan Google Classroom di dalamnya, dia bisa mudah memberikan pekerjaan rumah digital kepada murid-muridnya dan memberikan tanggapan secara langsung kapanpun dan dimanapun. (Afriyanti, 2018: 10-11).

Google Classroom merupakan media yang menyediakan kemudahan dalam pendistribusian materi pembelajaran maupun soal serta dapat digunakan sebagai sarana penilaian terhadap hasil kerja peserta didik dan melakukan interaksi dengan pengguna lainnya (Millatana, 2019: 77) 
PEMBAHASAN

Pelaksanaan Pembelajaran Daring / Jarak Jauh

Sebelum pelaksanaan pembelajaran daring dengan menggunakan media Google Classroom, untuk mengetahui sejauh mana kesesuaian materi pelajaran dengan pembelajaran menggunakan media Google Classroom dilakukan analisa kompetensi dasar terlebih dahulu. Adapun hasil analisis kompetensi dasar terhadap pembelajaran menggunakan media Google Classroom seperti tabel di bawah ini:

Tabel 1. Analisis kompetensi dasar terhadap pembelajaran menggunakan google classroom

\begin{tabular}{|c|c|c|c|}
\hline $\begin{array}{l}\text { Komptensi } \\
\text { Dasar }\end{array}$ & Indikator Pencapaian Kompetensi & Materi & $\begin{array}{l}\text { Kesesuaian } \\
\text { dengan } \\
\text { Google } \\
\text { Classroom }\end{array}$ \\
\hline \multirow[t]{3}{*}{3.7} & $\begin{array}{l}\text { 3,7.1 Menganalisis peristiwa sekitar } \\
\text { proklamasi }\end{array}$ & $\begin{array}{l}\text { Peristiwa sekitar proklamasi } \\
\text { proklamasi }\end{array}$ & Sesuai \\
\hline & $\begin{array}{l}\text { 3.7.2 Mendiskripsikan peran } \\
\text { peristiswa sekitar proklamasi }\end{array}$ & $\begin{array}{l}\text { Peran peristiswa sekitar } \\
\text { proklamasi }\end{array}$ & Sesuai \\
\hline & $\begin{array}{l}\text { 3.7.3 Menganalisis pembentukan } \\
\text { pemerintahan Rebublik } \\
\text { Indonesia }\end{array}$ & $\begin{array}{l}\text { Pembentukan pemerintahan } \\
\text { Republik Indonesia }\end{array}$ & Sesuai \\
\hline \multirow[t]{2}{*}{3.8} & $\begin{array}{l}\text { 3.8.1 Mendiskripsikan pelucutan } \\
\text { senjata tentara jepang }\end{array}$ & Pelucutan senjata tentara & Sesuai \\
\hline & $\begin{array}{l}\text { 3.8.2 } \begin{array}{l}\text { Menganalisis perjuangan } \\
\text { menghadapi kekuasaan Jepang }\end{array} \\
\text {. }\end{array}$ & $\begin{array}{l}\text { Perjuangan menghadapi } \\
\text { kekuasaan jepang }\end{array}$ & Sesuai \\
\hline \multirow[t]{2}{*}{3.9} & $\begin{array}{l}\text { 3.9.1 Menganalisis perjuangan } \\
\text { menghadapi kedatangan } \\
\text { Sekutu }\end{array}$ & $\begin{array}{l}\text { Perjuangan menghadapi } \\
\text { kedatangan Sekutu }\end{array}$ & Sesuai \\
\hline & $\begin{array}{l}\text { 3.9.2 } \text { Menganalisis perjuangan } \\
\text { menghadapi kedatangan } \\
\text { Belanda }\end{array}$ & $\begin{array}{l}\text { Perjuangan menghadapi } \\
\text { kedatangan Belanda }\end{array}$ & Sesuai \\
\hline \multirow[t]{2}{*}{3.10} & $\begin{array}{l}\text { 3.10.1 Mendiskripsikan perjuangan } \\
\text { menghadapi Belanda melalui } \\
\text { konfrontasi militer }\end{array}$ & $\begin{array}{l}\text { Perjuangan menghadapi } \\
\text { Belanda melalui } \\
\text { konfrontasi militer }\end{array}$ & Sesuai \\
\hline & $\begin{array}{l}\text { 3.10.2 } \text { Menganalisis perjuangan } \\
\text { menghadapi Belanda } \\
\text { melalui depkomasi }\end{array}$ & $\begin{array}{l}\text { Perjuangam menghadapi } \\
\text { Belanda melalui } \\
\text { deplomasi }\end{array}$ & Sesuai \\
\hline
\end{tabular}

Berdasarkan tabel tersebut menunjukan bahwa materi pelajaran pada kompetensi dasar 3.7, 3.8, 3.9 dan 3.10 ada kesesuaian atau dapat dilaksanakan dengan pembelajaran daring menggunakan aplilaksi Google Classroom.

Pembelajaran Sejarah pada kelas XI IPA 2 dengan jumlah 36 peserta didik dilaksanakan sesuai jadwal setiap hari selasa, pelaksanaannya paralel dengan kelas XI IPA 1. Pembelajaran dimulai tanggal 24 Maret 2020 berlangsung sampai dengan tanggal 12 Mei 2020, pukul 08.00 sampai dengan 09.30 WIB dengan jumlah pertemuan delapan kali. Buku pegangan peserta didik atau buku paket yang digunakan peserta didik, yaitu buku siswa Sejarah Indonesia SMA/MA/MK Kelas XI Kemendikbud Tahun 2018 dan lembar kerja siswa, serta buku referensi lainnya. Sedangkan materi pelajaran disesuaikan dengan silabus yaitu pada kompetensi dasar 3.7, 3.8, 3.9 dan 3.10. Adapun materi yang diajarkan dalam pembelajaran sebagai berikut:

a. Bab VI Indonesia Merdeka. Materinya antara lain; Peristiwa proklamasi kemerdekaan, Pembentukan pemerintahan Republik Indonesia; Peran tokoh peristiwa proklamasi

b. Bab VII Revolusi Menegakan Panji Panji NKRI. Materinya meliputi; Perjuangan menghadapi kekuasaan Jepang, Perjuangan menghadapi kedatangan Sekutu dan Belanda, perjuangan menghadapi ancaman Belanda melalui konfrontasi militer dan deplomasi.

Pada setiap pertemuan pelaksanaan pembelajaran daring pada kelas XI IPA 2 SMA Negeri 1 Sewon peserta didik diwajibkan untuk 
melakukan litarasi materi untuk mendalami materi buku teks pegangan siswa, lembar kerja siswa maupun ringkasan materi yang disiapkan guru. Dan diberikan tugas latihan soal dalam bentuk uraian, pilihan ganda maupun jawaban singkat. Batas waktu pengumpulan tugas dua hari setelah jadwal pembelajaran daring berlangsung. Data pengumpulan tugas peserta didik pada setiap pertemuan sebagai berikut :

Tabel 2. Data pengumpulan tugas peserta didik kelas XI MIPA 2

\begin{tabular}{|c|c|c|c|c|c|}
\hline \multirow{2}{*}{$\begin{array}{l}\text { Perte- } \\
\text { muan } \\
\mathrm{Ke}\end{array}$} & \multirow[t]{2}{*}{ Hari/Tgl } & \multicolumn{3}{|c|}{ Peserta Didik } & \multirow{2}{*}{$\begin{array}{l}\text { Keterangan } \\
\text { tugas peserta } \\
\text { didik }\end{array}$} \\
\hline & & $\begin{array}{l}\text { Mengumpulkan } \\
\text { tugas tepat } \\
\text { waktu }\end{array}$ & $\begin{array}{l}\text { Terlambat } \\
\text { mengumpulkan } \\
\text { tugas }\end{array}$ & $\begin{array}{l}\text { Tidak } \\
\text { mengumpulkan } \\
\text { tugas }\end{array}$ & \\
\hline 1 & $\begin{array}{l}\text { Selasa, } \\
23 \text { Maret } \\
2020\end{array}$ & $\begin{array}{c}33 \\
(91,7 \%)\end{array}$ & $\begin{array}{c}3 \\
(8,3 \%)\end{array}$ & $\begin{array}{c}0 \\
(0 \%)\end{array}$ & 5 soal uraian \\
\hline 2 & $\begin{array}{l}\text { Selasa, } \\
31 \text { Maret } \\
2020\end{array}$ & $\begin{array}{c}30 \\
(83,3 \%)\end{array}$ & $\begin{array}{c}6 \\
(16.7 \%)\end{array}$ & $\begin{array}{c}0 \\
(0 \%)\end{array}$ & $\begin{array}{l}25 \text { soal pilihan } \\
\text { ganda }\end{array}$ \\
\hline 3 & $\begin{array}{l}\text { Selasa, } \\
7 \text { April } \\
2020\end{array}$ & $\begin{array}{c}35 \\
(97,2 \%)\end{array}$ & $\begin{array}{c}1 \\
(2,8 \%)\end{array}$ & $\begin{array}{c}0 \\
(0 \%)\end{array}$ & $\begin{array}{l}12 \text { soal jawaban } \\
\text { singkat }\end{array}$ \\
\hline 4 & $\begin{array}{l}\text { Selasa, } \\
14 \text { April } \\
2020\end{array}$ & $\begin{array}{c}35 \\
(97,2 \%)\end{array}$ & $\begin{array}{c}1 \\
(2,8 \%)\end{array}$ & $\begin{array}{c}0 \\
(0 \%)\end{array}$ & 5 soal uraian \\
\hline 5 & $\begin{array}{l}\text { Selasa, } \\
21 \text { April } \\
2000\end{array}$ & $\begin{array}{c}32 \\
(88,9 \%)\end{array}$ & $\begin{array}{l}4 \\
(11.1 \%)\end{array}$ & $\begin{array}{c}0 \\
(0 \%)\end{array}$ & 6 soal uraian \\
\hline 6 & $\begin{array}{l}\text { Selasa, } \\
28 \text { April } \\
2000\end{array}$ & $\begin{array}{c}26 \\
(72.2 \%)\end{array}$ & $\begin{array}{c}10 \\
(27.8 \%)\end{array}$ & $\begin{array}{c}0 \\
(0 \%)\end{array}$ & $\begin{array}{l}10 \text { soal jawaban } \\
\text { singkat }\end{array}$ \\
\hline 7 & $\begin{array}{l}\text { Selasa, } \\
5 \mathrm{Mei} \\
2000\end{array}$ & $\begin{array}{c}27 \\
(75.0 \%)\end{array}$ & $\begin{array}{c}9 \\
(25,0 \%)\end{array}$ & $\begin{array}{c}0 \\
(0 \%)\end{array}$ & $\begin{array}{l}15 \text { soal jawaban } \\
\text { singkat }\end{array}$ \\
\hline 8 & $\begin{array}{l}\text { Selasa, } \\
12 \mathrm{Mei} \\
2020 \\
\end{array}$ & $\begin{array}{c}36 \\
(100 \%)\end{array}$ & $\begin{array}{c}0 \\
(0 \%)\end{array}$ & $\begin{array}{c}0 \\
(0 \%)\end{array}$ & $\begin{array}{l}\text { literasi materi } \\
\text { semester genap dan } \\
\text { pengisian angket }\end{array}$ \\
\hline
\end{tabular}

Berdasarkan tabel diatas menujukan bahwa peserta didik yang mengumpulkan tugas tepat waktu paling banyak pada pertemuan ke delapan yaitu 36 (100\%) peserta didik, sedangkan yang mengumpulkan tugas tepat waktu paling sedikit pada pertemuan ke enam $26(72 \%)$ peserta didik. Peserta didik yang mengumpulkan tugas terlambat paling banyak pada pertemuan ke enam yaitu $10(27,8 \%)$ peserta didik, sedangkan yang mengumpulkan tugas terlambat paling sedikit pada pertemuan ke delapan $0(0 \%)$ peserta didik. Peserta didik yang tidak mengumpulkan tugas pertemuan pertama sampai dengan pertemuan ke delapan $0(0 \%)$.

Hasil konfirmasi dengan peserta didik bahwa keterlambatan mengumpulkan tugas disebabkan antara lain:
1) Kuota internet peserta didik tidak mencukupi untuk mengakses pembelajaran daring Google Classroom

2) Adanya kendala koneksi internet yang kurang bagus

3) Banyak tugas yang diberikan oleh guru mata pelajaran lainnya sehingga dalam menyelesaikan tugas dilakukan urut menyesuaikan batas akhir pengumpulan tugas yang diberikan oleh guru atau mata pelajaran lainnya.

4) Adanya kecenderungan peserta didik untuk menunda-nunda waktu dalam mengerjakan tugas yang diberikan guru.

Adapun hasil penilaian tugas selama pembelajaran daring dengan menggunakan Google Classroom pada mata pelajaran sejarah kelas XI MIPA 2 SMA Negeri 1 Sewon pada setiap Kompetensi Dasar (KD) sebagi berikut 
Tabel 3. Rekapitulasi nilai peserta didik kelas XI MIPA 2

\begin{tabular}{rccccc}
\hline No & Nilai & KD 3.7 & KD 3.8 & KD 3.9 & KD 3.10 \\
\hline 1 & $75<$ & $0(0 \%)$ & $0(0 \%)$ & $1(2,8 \%)$ & $3(8,3 \%)$ \\
\hline 2 & $75-79$ & $2(5,6 \%)$ & $0(0 \%)$ & $2(5,6 \%)$ & $5(13,9 \%)$ \\
\hline 3 & $80-84$ & $21(58,3 \%)$ & $12(33,3 \%)$ & $11(30,6 \%)$ & $5(13,9 \%)$ \\
\hline 4 & $85-89$ & $13(36,1 \%)$ & $16(44,4 \%)$ & $18(50,0 \%)$ & $14(38,9 \%)$ \\
\hline 5 & $90-94$ & $0(0 \%)$ & $8(22,2 \%)$ & $4(11,1 \%)$ & $5(13,9 \%)$ \\
\hline 6 & $95-100$ & $0(0 \%)$ & $0(0 \%)$ & $0(0 \%)$ & $4(11,1 \%)$ \\
\hline
\end{tabular}

Berdasarkan tabel diatas menunjukan bahwa 1) Pada Kompetensi Dasar 3.7 nilai paling rendah dengan nilai 75 - 79 terdapat 2 $(5,6 \%)$ peserta didik, sedangkan nilai paling tinggi dengan nilai $85-89$ terdapat $13(36,1 \%)$ peserta didik. 2) Pada Kompetensi Dasar 3.8 nilai paling rendah dengan nilai 80 - 84 terdapat $12(33,3 \%)$ peserta didik, sedangkan nilai paling tinggi dengan nilai $90-94$ terdapat 8 (22,2\%) peserta didik. 3) Pada Kompetensi Dasar 3.9 nilai paling rendah dengan nilai $<75$ terdapat $1(2,8 \%)$ peserta didik, sedangkan nilai paling tinggi dengan nilai 90 - 94 terdapat 4 (11,1\%) peserta didik. 4) Pada Kompetensi Dasar 3.10 nilai paling rendah dengan nilai $<75$ terdapat $3(8,3 \%)$ peserta didik, sedangkan nilai paling tinggi dengan nilai 95 - 100 terdapat 4 $(11,1 \%)$ peserta didik.

\section{Kelebihan dan Kekurangan Pembelajaran Google Classroom}

Adapun kelebihan Pelaksanaan pembelajaran sejarah menggunakan Google Claasroom pada kelas XI MIPA 2 sebagai berikut

a. Guru dan peserta didik menjadi terbiasa menggunakan pembelajaran secara daring.

b. Guru ingin mencoba menggunakan fasilitas pembelajaran daring lainnya selain Goggle Classroom

c. Guru dalam mengajar bisa hikmat waktu dalam mengelola kelas d. Memudahkan peserta didik dan guru untuk saling terhubung di dalam dan di luar sekolah.

Sedangkan beberapa kekurangannya antara lain adalah sebagai berikut:

a. Guru dan peserta didik tidak dapat bertatap muka langsung dalam pembelajaran.

b. Pengeluran semakin bertambah untuk membeli pulsa, quota

c. Perlu sarana prasarana yang memadai hand phone, laptop/computer maupun jaringan internet

d. Apabila sarana kurang terpenuhi dapat menghambat pembelajaran.

\section{Makna Nilai Nilai Pembelajaran Sejarah}

Setelah peserta didik mempelajari peristiwa sejarah perjuangan perang kemerdekaan Indonesia tahun 1945 sampai dengan tahun 1949, pada akhir pertemuan ke delapan guru memberi tugas kepada peserta didik untuk mengisi angket pemahaman dan penanaman nilai nilai pembelajaran sejarah kepada peserta didik melalui Google Classroom. Tujuan dari pengisian angket untuk mengetahui sejauh mana pemahaman materi sejarah yang telah dipelajari dan nilai nilai manfaat pembelajaran sejarah bagi kehidupan sehari hari.

Hasil rekapitulasi tanggapan peserta didik terhadap angket pemahaman materi dan penanaman nilai nilai pembelajaran sejarah seperti tabel di bawah ini; 
Tabel 4. Rekapitulasi angket pemahaman materi dan nilai-nilai pembelajaran sejarah kelas XI MIPA 2

\begin{tabular}{|c|c|c|c|c|c|c|}
\hline $\mathrm{NO}$ & Pernyataan & $\begin{array}{l}\text { Sangat } \\
\text { Tidak } \\
\text { Setuju }\end{array}$ & $\begin{array}{l}\text { Tidak } \\
\text { Setuju }\end{array}$ & $\begin{array}{l}\text { Biasa } \\
\text { Saja }\end{array}$ & Setuju & $\begin{array}{l}\text { Sangat } \\
\text { Setuju }\end{array}$ \\
\hline 1 & $\begin{array}{l}\text { Setelah mempelajari materi; } \\
\text { Peristiwa sekitar proklamasi kemerdekaan } \\
\text { Indonesia terdapat penanaman nilai nilai } \\
\text { sabar dan bijaksana menghadapi masalah }\end{array}$ & $\begin{array}{c}0 \\
0 \%\end{array}$ & $\begin{array}{c}0 \\
0 \%\end{array}$ & $\begin{array}{c}2 \\
5,6 \%\end{array}$ & $\begin{array}{c}12 \\
33,3 \%\end{array}$ & $\begin{array}{l}22 \\
61,1 \%\end{array}$ \\
\hline 2 & $\begin{array}{l}\text { Pembentukan pemerintahan Republik } \\
\text { Indonesia terdapat penanaman nilai nilai } \\
\text { kerja keras dalam mencapai tujuan }\end{array}$ & $\begin{array}{c}0 \\
0 \%\end{array}$ & $\begin{array}{c}0 \\
0 \%\end{array}$ & $\begin{array}{c}1 \\
2,8 \%\end{array}$ & $\begin{array}{c}14 \\
38,9 \%\end{array}$ & $\begin{array}{c}21 \\
58,3 \%\end{array}$ \\
\hline 3 & $\begin{array}{l}\text { Peran tokoh peristiwa sekitar proklamasi } \\
\text { lainnya terdapat nilai nilai rela berkorban } \\
\text { tanpa pamrih }\end{array}$ & $\begin{array}{c}0 \\
0 \%\end{array}$ & $\begin{array}{c}0 \\
0 \%\end{array}$ & $\begin{array}{c}4 \\
11,1 \%\end{array}$ & $\begin{array}{l}10 \\
27 \%\end{array}$ & $\begin{array}{l}22 \\
61,1 \%\end{array}$ \\
\hline 4 & $\begin{array}{l}\text { Perjuangan menghadapi kekuasaan Jepang } \\
\text { terdapat penanaman nilai nilai pantang } \\
\text { menyerah dalam merebut kemerdekaan }\end{array}$ & $\begin{array}{c}0 \\
0 \%\end{array}$ & $\begin{array}{c}0 \\
0 \%\end{array}$ & $\begin{array}{c}2 \\
5,6 \%\end{array}$ & $\begin{array}{c}12 \\
33,3 \%\end{array}$ & $\begin{array}{c}22 \\
61,3 \%\end{array}$ \\
\hline 5 & $\begin{array}{l}\text { Perjuangan menghadapi kedatangan Sekutu } \\
\text { dan Belanda di Indonesia terdapat } \\
\text { penanaman nilai nilai nasionalisme } \\
\text { mempertahankan kemerdekaan }\end{array}$ & $\begin{array}{l}0 \\
0 \%\end{array}$ & $\begin{array}{c}0 \\
0 \%\end{array}$ & $\begin{array}{c}2 \\
5,6 \%\end{array}$ & $\begin{array}{c}11 \\
30,6 \%\end{array}$ & $\begin{array}{c}23 \\
63,9 \%\end{array}$ \\
\hline 6 & $\begin{array}{l}\text { Perjuangan menghadapi ancaman Belanda } \\
\text { melalui melalui konfrontasi militer terdapat } \\
\text { nilai nilai cinta tanah air bangsa dan negara }\end{array}$ & $\begin{array}{c}0 \\
0 \%\end{array}$ & $\begin{array}{c}0 \\
0 \%\end{array}$ & $\begin{array}{c}2 \\
5,6 \%\end{array}$ & $\begin{array}{c}11 \\
30,6 \%\end{array}$ & $\begin{array}{c}23 \\
63,9 \%\end{array}$ \\
\hline 7 & $\begin{array}{l}\text { Perjuangan menghadapi ancaman Belanda } \\
\text { melalui melalui jalur diplomasi terdapat nilai } \\
\text { saling menghargai hasil keputusan bersama }\end{array}$ & $\begin{array}{c}0 \\
0 \%\end{array}$ & $\begin{array}{c}0 \\
0 \%\end{array}$ & $\begin{array}{c}1 \\
2,8 \%\end{array}$ & $\begin{array}{c}14 \\
38,9 \%\end{array}$ & $\begin{array}{c}21 \\
58,3 \%\end{array}$ \\
\hline
\end{tabular}

Berdasarkan tabel di atas menujukan bahwa 1) Peserta didik yang memilih biasa saja paling tinggi pada nilai rela berkorban tanpa pamrih sejumlah $4(11,1 \%)$, sedangkan yang paling rendah pada nilai kerja keras, dan saling menghargai masing-masing sejumlah $1(2,8 \%)$ peserta didik. 2) Peserta didik yang memilih setuju paling tinggi pada nilai kerja keras, dan nilai saling menghargai masing-masing sejumlah $14(38,9 \%)$, sedangkan yang paling rendah pada nilai rela berkorban tanpa pamrih sejumlah 10 (27,8\%) peserta didik. 3) Peserta didik yang memilih sangat setuju paling tinggi pada nilai nasionalisme, dan cinta tanah air masing-masing sejumlah 23 (63,9\%), sedangkan yang paling rendah pada nilai kerja keras, dan nilai saling menghargai masingmasing sejumlah $21(58,3 \%)$, peserta didik.

Dengan demikian manfaat pembelajaran daring pada mata pelajaran sejarah menggunakan Google Classroom ternyata banyak pengalaman yang diperoleh peserta didik antara lain, bertambahnya pengetahuan materi sejarah dan makna nilai nilai pembelajaran sejarah yaitu terbentuk sikap karakter bagi peserta didik sebagai generasi penerus bangsa.
Pembelajaran sejarah menggunakan Google Classroom kedepan perlu dilaksanakan tidak sebatas sebatas karena ada wabah pandemic covid-19, untuk menghadapi tatangan ke depan di era revolusi industri abad 4.0.

Sekolah perlu memfasilitasi peningkatan sumber daya manusia dengan mengadakan workhop pembelajaran daring metode pembelajaran jarak jauh lainnya, sehingga guru semakin professional dalam menghadapi tantangan kemajuan tehnologi informasi dalam meningkatan kemajuan pendidikan.

\section{SIMPULAN DAN SARAN}

Berdasarkan tulisan artikel ini dapat ditarik kesimpulan sebagai berikut:

1. Pembelajaran sejarah menggunakan Google Classroom masa pandemic covid-19 pada kelas XI MIPA 2 di SMA Negeri 1 Sewon bermanfaat bagi peserta didik bagi peserta didik yaitu dapat mengatahui sejarah peristiwa sekitar proklamasi kemerdekaan Indonesia dan upaya Bangsa Indonesia mempertahankan kemerdekaan melawan Sekutu dan Belanda. 
2. Kelebihan penggunaan Google Classroom, guru dan peserta didik menjadi terbiasa menggunakan pembelajaran daring. Hambatan penggunaan Google Classroom, guru dan peserta didik tidak dapat bertatap muka langsung dalam pembelajaran. Apabila sarana kurang memadai dapat menghambat pelaksanaan pembelajaran daring.

3. Nilai-nilai mempelajari materi sejarah revolusi kemerdekaan Indonesia antara lain: 1) sabar dan bijaksana; 2) kerja keras; 3) rela berkorban tanpa pamrih; 4) pantang menyerah; 5) nasionalisme; 6) cinta tanah air; 7) saling menghargai. Nilai-nilai karakter tersebut sangat penting bagi peserta didik sebagai modal untuk membangun dan mengisi kemerdekaan bangsa Indonesia tercinta.

Beberapa saran yang dapat disampaikan tulisan artikel ini antara lain:

1. Pembelajaran daring/jarak perlu dilanjutkan tidak sebatas hanya berlangsung pada masa pandemi covid-19, tetapi dalam rangka menghadapi tantang perkembangan era revolusi industri abad 4.0.

2. Pemerintah dalam hal ini Kementerian Pendidikan dan Kebudayaan dan Dinas Pendidikan Pemuda dan Olahraga Daerah Istimewa Yogyakarka perlu memberikan bantuan pendanaan terlaksananya pembelajaran daring/jarak dapat berjalan optimal.

3. Kementerian Pendidikan dan Kebudayaan dan Lembaga Penjaminan Mutu Pendidikan perlu merencanakan peningkatan sumber daya manusia bagi guru tentang pembelajaran daring/ jarak jauh.

4. Dalam menyusun Rencana Anggaran Kegiatan Sekolah hendaknya memasukan kegiatan workshop pembelajaran daring / jarak jauh untuk meningkatkan profesinalisme guru.

\section{DAFTAR PUSTAKA}

Afriyani, W. E. (2018). Penerapan Google Classroom Dalam Pembelajaran Akuntansi https://dspace.uii.ac.id/bitstream/handle/123 456789/6173/SKRIPSI.pdf? sequence $=1$

BSNP. (2006). Standar Isi untuk Satuan Pendidikan Dasar dan Menengah: Standar Kompetensi dan Kompetensi Dasar SMA/MA. Jakarta: BSNP.

Hamalik, O. (2001). Proses Belajar Mengajar. Jakarta: Bumi aksara.

Marli, S. (2011). Sejarah dan Pendidikan Sejarah. Jurnal Cakrawala Kependidikan, Vol 9 No. 2, 2011

Millatana, M. E. (2019). Peningkatan Prestasi Belajar Matrik dengan Pembelajaran Blanded Learning Berbantuan Google Classroom di Kelas XI IPS 1 SMA Negeri 7 Yogyakarta. Jurnal Ide Guru, Vol.4 No.2, 2019

Munir. (2012). Pembelajaran Jarak Jauh Berbasis Teknologi Informasi dan Komunikasi, Alfabeta. Bandung

Prasetiya, M. (2018), Metode Pembelajaran Pendidikan Dalam Menghadapi Revolusi Industri $4.0 \quad \mathrm{http}: / / \mathrm{pmbs} . \mathrm{ac} . \mathrm{id} / \mathrm{news} /$ Metode_ Pembelajaran_ Pendidikan_ Dalam Menghadapi_Revolusi_Industri_4.0

Puspitasari, R. (2020), Hikmah Pandemi Covid-19 bagi Pendidikan Di Indonesia https://iain-surakarta.ac.id/hikmah-pandemicovid-19-bagi- pendidikan-di-indonesia/

Sardiman, A.M. (2009). Interaksi dan Motivasi Belajar. Jakarta: Raja Grafindo Persada.

Surat Edaran Kemendikbud Nomor 4 Tahun 2020 tentang Pelaksanaan Kebijakan Pendidikan Masa Darurat Covid-19

Sutikno, M. S. (2013). Belajar dan Pembelajaran, Lombok, Holistica

Undang-undang Nomor 20 tahun 2003 tentang Sistem Pendidikan Nasional 